\title{
Progesterone only pills: an effective contraceptive option for lactating women
}

\author{
Michelle Fonseca, Prasad Yeshwant Deshmukh*, Deepali Kharat
}

Department of Obstetrics and Gynecology, LTMMC and GH, Sion, Mumbai, Maharashtra, India

Received: 18 July 2017

Accepted: 18 August 2017

\section{*Correspondence:}

Dr. Prasad Yeshwant Deshmukh,

E-mail: drpydeshmukh@gmail.com

Copyright: (C) the author(s), publisher and licensee Medip Academy. This is an open-access article distributed under the terms of the Creative Commons Attribution Non-Commercial License, which permits unrestricted non-commercial use, distribution, and reproduction in any medium, provided the original work is properly cited.

\section{ABSTRACT}

Background: Progesteone only pills (POP) are the most suitable for breastfeeding women as they have no effect on quality and quantity of breast milk in lactating women or on infant growth as well.

Methods: A study was conducted on post partum lactating women over a period of 6 months at a tertiary care hospital in Mumbai. Post partum women were called for follow up in the post natal OPD and were counseled about temporary and permanent spacing methods.

Results: Progesterone only pills are an acceptable and convenient means of temporary contraception / spacing during lactation period in motivated patients who do not want IUCDs or Injectables or are undecided about permanent methods of family planning.

Conclusions: Low Dose progesterone only minipill is both effective and acceptable to breast feeding women. It may be used as a temporary spacing method in women who do not prefer an IUD but who are motivated to be complaint with its use.

Keywords: Amenorrhoea, Breastfeeding, Irregular spotting, Progesterone only pills

\section{INTRODUCTION}

Combined oral contraceptive pills are a popular choice for reversible contraception today. However, the use of estrogens can adversely affect the quality and composition of breast milk in lactating women. Also, the possibility of adverse effects in women with risk factors for arterial and venous thrombosis precludes their use in certain cases. ${ }^{1}$

Progesteone only pills (POP) are the most suitable for breastfeeding women as they have no effect on quality and quantity of breast milk in lactating women or on infant growth as well., ${ }^{2,3}$ Each tablet contains $75 \mathrm{mg}$ (microgrammes) of desogestrel, which is metabolised to etonorgestrel. Etonorgestrel is a selective progestogen with high affinity for progesterone receptors and low affinity for androgen receptors compared to other progestogens. ${ }^{1}$ A high dose can be used to inhibit ovulation without increasing androgenic side effects. ${ }^{3}$ The primary working mechanism of Progesterone only pills are inhibition of ovulation. The secondary effect is thickening of cervical mucus. Also, the consistent inhibition of ovulation in the newer POPs (containing 75 micrograms of Desogestral only) has resulted in Pearl Index of 0.14 , which is comparable to that reported for traditional POPs. ${ }^{4,5}$ Double dosing of pills was proposed some years ago when it was noticed in an Oxford-Family Planning Association study (1985) that women with increasing weight appeared to have a higher failure rate than those with a lower weight, regardless of body mass index. However, further studies failed to corroborate this so advice to women weighing over $70 \mathrm{~kg}$ to take two progestogen-only pills daily has been dropped. ${ }^{5}$ 
Low dose Progesterone only pills (also commonly called the mini pill) could be used as a suitable alternative to combined OC pills in lactating women.

\section{METHODS}

A study was conducted on post partum lactating women over a period of 6 months at a tertiary care hospital in Mumbai. Post partum women were called for follow up in the post natal OPD and were counseled about temporary and permanent spacing methods. 44 women who opted for the Minipill were put on a 28 day pack of a progesterone only pill containing 75 micrograms of Desogestrel. Patients were advised to start the pill on day 28 to day 30 following normal delivery / LSCS. They were advised to take the pills without a break but report every 28 days for follow up in the OPD and maintain a menstrual calendar. All patients were counseled regarding possible menstrual side effects. Patients were followed up over 6 months.

Following data was recorded meticulously

- Epidemiological data

- General medical history

- Gynaecological and Obstetric history

- Contraceptive history

- $\quad$ Past history of DVT

- Any concomitant medication (if present)

In every visit, following data was recorded

- Body weight, blood pressure

- $\quad$ Pregnancy test (if suspected)

- Physical complaints

- Menstrual Diary cards for vaginal bleeding as "B" for bleeding and " $\mathrm{S}$ " for spotting and " $\mathrm{X}$ "for forgotten pills

- Adverse reactions (if any)

\section{Inclusion criteria}

- Women who are post partum and breast feeding.

- Women who are not willing for IUD but are willing for oral contraception.

\section{Exclusion criteria}

- Active venous thromboembolism

- Presence of hepatic disease

- Hypersensitivity to OC Pills

- Known or suspected pregnancy

- Undiagnosed vaginal bleeding

\section{RESULTS}

In the present study, (Table 1) most of the women $(45.45 \%)$ recruited were second gravida. This may be due to the fact that although they wanted contraception, they were scared to insert IUD, however they were willing to use a contraceptive that did not affect breastfeeding.

Table 1: Parity.

\begin{tabular}{|lll|}
\hline No. of pregnancies & No. of women & $\%$ \\
\hline Nullipara & 0 & 0 \\
\hline Primigravida & 19 & 43.18 \\
\hline Second Gravida & 20 & 45.45 \\
\hline Third Gravida & 5 & 11.37 \\
\hline
\end{tabular}

Table 2: Side effects.

\begin{tabular}{|lll|}
\hline Side effect & No. of Women & $\%$ \\
\hline Irregular bleeding/spotting & 28 & 63.63 \\
\hline Amenorrhoea & 16 & 36.36 \\
\hline Acne & 1 & 2.27 \\
\hline Weight gain & 6 & 13.63 \\
\hline Dysmenorrhoea & 1 & 2.27 \\
\hline
\end{tabular}

In Table 2 most of the women (63.63\%) recorded their side effect as irregular vaginal bleeding which was a cause of concern as it interfered with religious practices in some women.

The other common side effect recorded was amenorrhoea $(36.36 \%)$ which was acceptable as it is an accepted fact that lactating women do not menstruate! One patient discontinued because of weight gain of $3 \mathrm{~kg}$ which she attributed to the pill.

Table 3: Vaginal bleeding patterns in women on progesterone only pill.

\begin{tabular}{|ll|l|}
\hline Bleeding pattern & No. of women & $\%$ \\
\hline Amenorrhoea & 16 & 36.36 \\
\hline 1-2 bleeding/spotting episodes & 11 & 25 \\
\hline 3-5 bleeding/spotting episodes & 4 & 9.09 \\
\hline >5 bleeding/spotting episodes & 13 & 29.54 \\
\hline
\end{tabular}

On detailed inquiry into pattern of vaginal bleeding 16 women had amenorrhoea and 11 women had only 1-2 episodes of vaginal spotting episodes. 13 patients complained of more than 5 spotting episodes times in a cycle (Table 3 ). This could have been due to irregular pill intake or differential response by every women during postpartum period but this was also the major cause of discontinuation of this pill.

Table 4: Continuation rate.

\begin{tabular}{|lll|}
\hline Follow up at 6 months & Number & $\%$ \\
\hline Continued on the pill & 21 & 47.72 \\
\hline Discontinued & 17 & 38.63 \\
\hline Lost to follow up & 6 & 13.63 \\
\hline
\end{tabular}

Table 4 shows that follow up at the end of 6 months, most of women $(50 \%)$ had continued the pill use. And they found it to be a satisfactory mode of contraception. 
Table 5: Reasons for discontinuation.

\begin{tabular}{|lll}
\hline Reason & Number & $\%$ \\
\hline Irregular spotting/bleeding & 13 & 29.54 \\
\hline Forgot to take pills & 3 & 6.81 \\
\hline Weight gain & 1 & 2.27 \\
\hline
\end{tabular}

Among those who discontinued the pill use, maximum women had irregular vaginal bleeding as the main reason for attrition (Table 5).

\section{DISCUSSION}

Progesterone only pills are an acceptable and convenient means of temporary contraception/spacing during lactation period in motivated patients who do not want IUCDs or Injectables or are undecided about permanent methods of family planning.

However, patients should be well counselled and have to be motivated and be complaint to take the medications on time. Desogestrel minipills if taken regularly have excellent contraceptive efficacy. The major reason for drop out is the episodes of spotting/ bleeding which are not acceptable to some women. During the first few months of use, the vaginal bleeding pattern is more variable but with continuous use the bleeding episodes become less frequent which makes it more acceptable to the patient. ${ }^{6,7}$

These pills should be avoided in patients on AKT (Rifampicin), or in patients on anticonvulsant drugs which may induce the hepatic enzymes responsible for metabolizing hormones. Clinically they have no important effect on blood pressure or liver function hence can be given in those patients in whom estrogens are contraindicated..$^{8-10}$

\section{CONCLUSION}

Low Dose progesterone only minipill is both effective and acceptable to breast feeding women. It may be used as a temporary spacing method in women who do not prefer an IUD but who are motivated to be complaint with its use. Also, neither it has effect on quality and quantity of milk produced nor on infant growth. Hence, it can be offered as the first choice in lactating women as birth spacing tool.

Funding: No funding sources Conflict of interest: None declared

Ethical approval: The study was approved by the Institutional Ethics Committee

\section{REFERENCES}

1. Horta B, Bahl R, Martines J, Victora C. Evidence of the long-term effects of breastfeeding; systematic review and meta-analysis. World Health Organization; Geneva, Switzerland;2007.

2. Gartner LM, Morton J, Lawrence RA, Naylor AJ, O'Hare D, Schanler RJ et al. Breastfeeding and the use of human milk. Pediatrics. 2005;115(2):496-506.

3. Diaz S, Peralta O, Juez G, Herreros C, Casado ME, Salvatierra AM et al. Fertility regulation in nursing women: III. Short-term influence of a low-dose combined oral contraceptive upon lactation and infant growth. Contraception. 1983;27(1):1-11.

4. Morbidity and Mortality Weekly Report (MMWR). Update to CDC's U.S. Medical Eligibility Criteria for Contraceptive Use, 2010: Revised Recommendations for the Use of Contraceptive Methods During the Postpartum Period. Weekly. 2011;60(26);878-883

5. Lawrie TA, Helmerhorst FM, Maitra NK, Kulier R, Bloemenkamp K, Gülmezoglu AM. Types of progestogens in combined oral contraception: effectiveness and side-effects. Cochrane Database Syst Rev. 2011;(5):CD004861.

6. New Mexico Department of Health. New Mexico Pregnancy Risk Assessment Monitoring System (PRAMS). Surveillance Report 2008. Retrieved May 9, 2011. Available at https://nmhealth.org/about/phd/fhb/prams/

7. Hatcher RA, Trussell J, Nelson AL, Cates W, Kowal D. Contraceptive technology. $20^{\text {th }}$ ed. Ardent Media Inc; New York;2012.

8. ACOG Committee on Practice BulletinsGynecology. ACOG Practice bulletin \#73, Use of Hormonal contraception in women with coexisting medical conditions. Obstet Gynecol. 2006;107(6):1453-72.

9. WHO. WHO medical eligibility criteria. Fifth edition 2015. Available at http://apps.who.int/iris/bitstream/10665/172915/1/W HO_RHR_15.07_eng.pdf

10. International Planned Parenthood Federation: directory of hormonal contraceptives medical and service delivery guidelines. 3rd ed. 2004. Available at

http://www.ippf.org/sites/default/files/ippf_medical_ and_service_delivery_guidelines_english.pdf

Cite this article as: Fonseca M, Deshmukh PY, Kharat D. Progesterone only pills: an effective contraceptive option for lactating women. Int $\mathbf{J}$ Reprod Contracept Obstet Gynecol 2017;6:43994401 . 